\title{
Influence of Foliar Application of Pulse Magic on Seed Yield and Economics of Pigeon Pea
}

\author{
Avinash", J. R. Patil and R. P. Patil \\ Department of Crop Physiology, University of Agriculture Sciences, Raichur, India \\ *Corresponding author
}

\section{A B S T R A C T}

\begin{tabular}{|l|}
\hline Ke y w o r d s \\
Pigeon pea, Pulse \\
Magic, Economics, \\
$\begin{array}{l}\text { Yield attributes and } \\
\text { Yield }\end{array}$ \\
\hline Article Info \\
\hline $\begin{array}{l}\text { Accepted: } \\
15 \text { July 2020 } \\
\text { Available Online: } \\
10 \text { August } 2020\end{array}$ \\
\hline
\end{tabular}

Pigeon pea is majorly grown in north-eastern dry zone of Karnataka and it carries a unique position in every cropping system of this zone. Crop Productivity of pigeonpea is being low in the north-eastern dry zone of Karnataka and this is due to several reasons. One of the main important reason is flower drop and poor seed setting. To overcome and reduce this problem and to enhance productivity of pigeonpea, the Krishi Vigyan Kendra (KVK), Kalburgi, has introduced a product known as Pulse Magic (consists of nutrients and Plant growth regulators) as foliar spray. Foliar spray was carried out during $50 \%$ flowering stage and 15 days after $1^{\text {st }}$ Spray. The results obtained due to foliar spray of Pulse Magic were higher number of pods per plant (212.91), pod weight per plant $(78.08 \mathrm{~g})$, pod length $(5.63 \mathrm{~cm})$ and test weight $(12.48 \mathrm{~g})$, compared to control $(120.82,48.70 \mathrm{~g}, 3.9 \mathrm{cmand} 9.45 \mathrm{~g}$, respectively). Due to increase in yield attributes higher seed yield was obtained (1442 $\mathrm{kg} / \mathrm{ha})$, as compared to control (1182 kg/ha). Consequent upon higher yield, higher net returns (Rs.53903/ha) were obtained in Pulse Magic sprayed plot compared to control (Rs.35647/ha).

\section{Introduction}

Food legumes contribute significantly to dietary protein supply and fixation of atmospheric nitrogen (Ali, 2009). Pulses are important food crops due to their high protein and essential amino acid content. The seeds of pulse crops are usually made up of 20-25 per cent protein compared to $6-10 \%$ protein content in major cereal crops. Pulses are the important source of protein in the diet of vegetarians. Moreover, in recent years there is a change in the consumption of pulses in several developed countries where they are increasingly considered as healthy foods
(Allen et al., 1998). Thus, the food legumes ensure nutritional security to the poor masses of the country (Chaturvedi et al., 2002), also helps in solubilizing insoluble phosphorous in soil, improving the soil physical environment, enhances soil microbial activity, restoring organic matter and also have smothering effect on weeds (Ghosh et al., 2016). Legumes contain certain phytochemicals such as polyphenols, flavonoids and phytosterols that possess health benefits (Sreerama et al., 2010).

Among grain legumes, pigeon pea (Cajanus cajan L.) is grown extensively in North 
Eastern Dry Zone of Karnataka. It can be cultivated in wide range of soils, from sandy to heavy soils. It tolerates drought conditions during dry seasons but not frost during any stage of its growth. It adapted better way to marginal climatic conditions than any other pulse crops (Choudhury et al., 2008). Pigeon pea is a multipurpose crop, used for fodder, soil fertility enhancement, soil erosion control and for fuel. Deeper root system of the crop helps in breaking the plough pans and enhances soil structure and hence called as crop of "Biological plough".

In India, major pigeonpea growing state includes Maharashtra, Uttar Pradesh, Madhya Pradesh, Karnataka, Gujarat, Telangana and Tamil Nadu. Pigeon pea occupies an area about 3.96 million hectares producing 2.56 million tonnes with an average productivity of $646 \mathrm{~kg}$ per hectare in India (Anon, 2016). Whereas, in Karnataka, it is cultivated over an area of 6.57 lakh ha. with a production of 2.42 lakh tonnes and having the average productivity of $368 \mathrm{~kg}$ per hectare (Anon, 2016).

Yield of pigeon pea is reducing and it is due to several reasons and one of the important reasons for low yield of pigeon pea is because of high level of flower abscission (70-96\%), leading to a much- reduced realization of sink potential (Saxena et al., 2006 and Tekale et al., 2009). Therefore, it has realized that reduced yield in pigeon pea is due to more vegetative growth, indeterminate growth habit, poor source-sink relationship, poor pod set resulting from the high flower and pod drops. So, it is very necessary to compensate for the higher rate of flower abscission in pigeon pea to increase the pod yield.

Among several strategies to boost the productivity of pigeon pea, foliar spray of nutrients may serve as one of the important strategies. Nutrients play vital role in increasing the seed yield in pulses (Chandrasekhar et al., 2003). Foliar spray is having advantage of quick and efficient utilization of nutrients, elimination of losses through leaching, fixation and regulating the uptake of nutrients by plants (Manonmani et al., 2009 and Rahman et al., 2014). Application of nutrients through foliar spray at appropriate stages of crop growth favors better utilization of nutrients and better performance of the crop (Anandhakrishnaveni et al., 2004). Keeping this in view, experiment is conducted to reduce flower drop and to enhance pod setting by using Pulse Magic spray. And it is conducted to demonstrate the productivity potential and economic benefit under farmer's conditions.

\section{Materials and Methods}

The field experiment was conducted during kharif2018 at Agricultural Research Station, Kalburgi, UAS Raichur under rainfed condition. It is located at a latitude of 17o 34' North, longitude of 760 79' East and an altitude of 478 meters above mean sea level. The soil of the experiment plot is clayey (Soil $\mathrm{pH}$ 8.3; EC 0.21 ds-1). The available soil nitrogen, phosphorus and potassium were $241,14.9$ and $280 \mathrm{~kg}$ ha- 1 respectively. The experiment was carried out in Randomized Complete Block Design (RCBD) with 10 treatments. The treatments were foliar spray of NPK (19:19:19) mixture @ 2\% (T1), 6 BAP @ 20ppm (T2), Salicylic acid @ 100ppm (T3), Pulse magic @ 10g/l(T4), Mono ammonium phosphate @ 2\% (T5), Zinc sulphate@0.5\%(T6),Boric acid @ 0.1\% (T7),Water spray(T8), Control (RDF) (T9),Absolute control(T10) with3 replications using TS3R variety and maintained spacing of 90×30 cm. Pulsemagic @ 10 g/l (Product developed and released by UAS, Raichur for enhancing the yield of pulse crops. It contains 10 percent nitrogen, 40 percent phosphorous, 3 percent micronutrient and 20 PPM plant 
growth regulator. Foliar spray was carried out at flowering stage. The data were analyzed statistically using the ' $F$ ' test and critical difference (C.D) was calculated.

\section{Results and Discussion}

It was well known that seed yield finally depends on yield attributing characters. In the present demonstration, higher yield attributing characters viz., number of pods per plant (212.91) and pod weight per plant (78.08g) and pod length $(5.63 \mathrm{~cm})$ were noticed in
Pulse Magic sprayed plots compared to control (120.82, $48.70 \mathrm{~g}$ and $3.9 \mathrm{~cm}$, respectively). It may beat tribute due to the application of nutrients and plant growth regulators at flowering and pod formation stage, has helped in more translocation of photosynthates to the developing pods which in turn results in better filing of grains, thus increasing the test weight $(12.48 \mathrm{~g})$ of the seeds compared to control $(9.45 \mathrm{~g})$. Our results of experiment are similar to the findings of Thakur et al., (2017) due to foliar spray of Pulse Magic in blackgram.

Table.1 Effect of foliar application of pulse magic on yield attributes and Yield of Pigeon pea

\begin{tabular}{|c|c|c|c|c|c|c|c|}
\hline Year & Treatments & $\begin{array}{l}\text { No of } \\
\text { pods/plant }\end{array}$ & $\begin{array}{l}\text { Pod } \\
\text { weight/plant }(g)\end{array}$ & $\begin{array}{l}\text { Pod } \\
\text { length } \\
\text { (cm) }\end{array}$ & $\begin{array}{l}100 \text { seed } \\
\text { weight }(\mathrm{g})\end{array}$ & $\begin{array}{l}\text { Seed yield } \\
\text { (kg / ha) }\end{array}$ & $\begin{array}{l}\% \text { increase } \\
\text { yield over } \\
\text { control }\end{array}$ \\
\hline \multirow[t]{2}{*}{ 2017-18 } & $\mathrm{T}_{1}$ - Pulse Magic spray & 212.91 & 78.08 & 5.63 & 12.48 & 1442 & 22 \\
\hline & $\mathrm{T}_{2^{-}}$Control(RDF) & 120.82 & 48.70 & 3.61 & 9.45 & 1182 & - \\
\hline
\end{tabular}

Table.2 Effect of foliar application of pulse magic on economics of Pigeonpea

\begin{tabular}{|l|l|c|c|c|c|}
\hline Year & Treatments & $\begin{array}{c}\text { Cost of } \\
\text { cultivation }\left(\mathbf{R s} . \mathbf{h a}^{-\mathbf{1}}\right)\end{array}$ & $\begin{array}{c}\text { Gross returns } \\
\left(\text { Rs. ha }^{-\mathbf{1}}\right)\end{array}$ & $\begin{array}{c}\text { Net returns } \\
\left(\mathbf{R s . ~ h a}^{-\mathbf{1}}\right)\end{array}$ & B:C ratio \\
\hline \multirow{2}{*}{$\mathbf{2 0 1 7 - 1 8}$} & $\mathrm{T}_{1}$ - Pulse Magic spray & 25395 & 78840 & 53903 & 3.10 \\
\cline { 2 - 6 } & $\mathrm{T}_{2}$ - Control(RDF) & 22895 & 58542 & 35647 & 2.55 \\
\hline
\end{tabular}

T1: Recommended dose of fertilizers with Pulse Magic spray

T2: Recommended dose of fertilizers only and NoPulse Magic spray

Direct positive effect of 100 seed weight (test weight) on seed yield was reported by Chandirakala and Raveendran (1998). In the present experiment, higher test weight was obtained in Pulse Magic spayed plots, which further increased the final seed yield to the extent of $22 \%$ compared to control (Table 1 ). Similarly, foliar applied macro and micronutrients at critical stages of the crop were very effectively absorbed and translocated to the developing pods, producing a greater number of pods and improves better filling in soybean was suggested by Jayabel et al., (1999).

One of the main reasons for increasing seed yield to the extent of $22 \%$ compared to control plot is reduction of flower and pod drop, as it is well known that in pigeon pea around 70-96\% flowers are abscised leading to poor yield and controlling that can help in achieving potential yield. Similar results of reduction in flower drop due to foliar spray of Pulse Magic have been reported by Teggelli et al., (2016) in pigeon pea. Further, due to increment in seed yield in Pulse Magic sprayed plot there was higher gross returns (Rs78840/ha) and net returns (Rs. 53903/ha) compared to control (Rs. 58542/ha and Rs.35647/ha, respectively) (Table 2).

In conclusion it has been well-established fact 
that in pigeon pea as much as around 70-96\% of flowers are shed or abscised, leading to poor yield. If this major problem is minimized then there will be the attainment of the productive potential of the crop and ultimately there will be sustainability achievement. This major problem can be minimized by foliar spray of Pulse Magic during 50\% flowering stage and then 15 days after first spray. The results obtained because of foliar application of Pulse Magic were higher yield attributes and due to higher yield attributes, there was an increment in yield to the extent of $22 \%$ in Pulse Magic sprayed plots as compared to control. Consequently, upon higher yield, higher income was obtained in Pulse Magic sprayed plots compared to control (check).

\section{References}

Ali, M. and Kumar S., 2009, Major technology advances in pulses. J. Food Legume., 23: $169-85$.

Allen, R.G., Pereira, L.S., Raes, D. and Smith M., 1998, Crop evapotranspiration guidelines for computing crop water requirements. FAO Irrigation and drainage paper 56. Food and Agriculture Organization, Rome.

Anandhakrishnaveni, S., Palchamy, A. and Mahendran S., 2004, Effect of foliar spray of nutrient on growth and yield of green gram (Phaseolu sradiatus). Legume Res., 27(2):149-150.

Anonymous, 2016, Coordinator's rep. All India coordinated res. Project on Pigeon pea (23).

Chandirakala, R. and Raveendran., 1998,TS. Crop Res., 16: 362-367.

Chandrasekhar, C.N. and Bangarusamy U., 2003, Maximizing the yield of mungbean by foliar application of growth regulating chemicals and nutrients. Madras Agric. J., 90(1- 3): 142-145.

Chaturvedi, S.K. and Ali, M., 2002, Poor man's meat needs fresh fillip. The Hindu Survey of Indian Agriculture, 63-69.

Choudhury, P.R., Singh, I.P., George, B.,
Verma, A.K. and Singh N.P., 2008, Assessment of genetic diversity of pigeon pea cultivars using RAPD analysis. Biol. Plantarum., 52: 648-53.

Ghosh, P.K., Bandyopadhya,K, K., Wanjari, R.H., Manna, M.C., Misra, A, K., Mohanty, M. and Subba Rao A., 2007, Legume effect for enhancing productivity and nutrient use- efficiency in major cropping systems-An Indian Perspective: $A$ Review. J. Sustain. Agr; 30: 59-86.

Jayabel, A., Revathy, M. and Saxena, M.G., 1999, Effect of foliar nutrition on nutrient uptake pattern in soybean. Andhra Agric. $J$; 46: 243- 244.

Manonmani, V. and Srimathi, P., 2009, Influence of mother crop nutrition on seed and quality of black gram. Madras Agric. J.; 96(16): 125-128.

Rahman, I.U.R., Afzal, A., Iqbal, Z. and Manan, S., 2014, Foliar application of plant mineral nutrients on wheat: A Review. RRJAAS., 3: 19- 22.

Saxena, K.B., Kumar, R.V., Madhavi, L.K. and Dalvi, V.A., 2006, Commercial pigeon pea hybrids are just a few steps away. Indian J. Pulses Res., 19: 7-16.

Sreerama, Y.N., Sashikala, V.B. and Pratape, V.M., 2010, Variability in the distribution of phenolic compounds in milled fractions of chickpea and horse gram: Evaluation of their antioxidant properties. J. Agric. Food Chem., 58: 8322-30.

Teggelli, R.G., Salagunda, S. and Ahamed, B.Z., 2016, Influence of pulse magic application on yield and economics oftransplanted pigeon pea. Int. J. Sci. Nat., 7(3): 598- 600.

Tekale, R.P., Guhey, A. and Agrawal K., 2009, Impact of boron, zinc and IAA on growth, dry matter accumulation and sink potential of pigeon pea (Cajanus cajan L). Agric. Sci. Digest., 29: 246-49.

Thakur., V., Patil, R.P., Patil, J.R, Suma, T.C. and Umesh, M.R., 2017, Physiological approaches for yield improvement of black gram under rainfed condition. Int. J. Curr. Microbiol. App. Sci., 6(11): 4114-4122. 


\section{How to cite this article:}

Avinash, J. R. Patil and Patil, R. P. 2020. Influence of Foliar Application of Pulse Magic on Seed Yield and Economics of Pigeon Pea. Int.J.Curr.Microbiol.App.Sci. 9(08): 1399-1403. doi: https://doi.org/10.20546/ijcmas.2020.908.159 